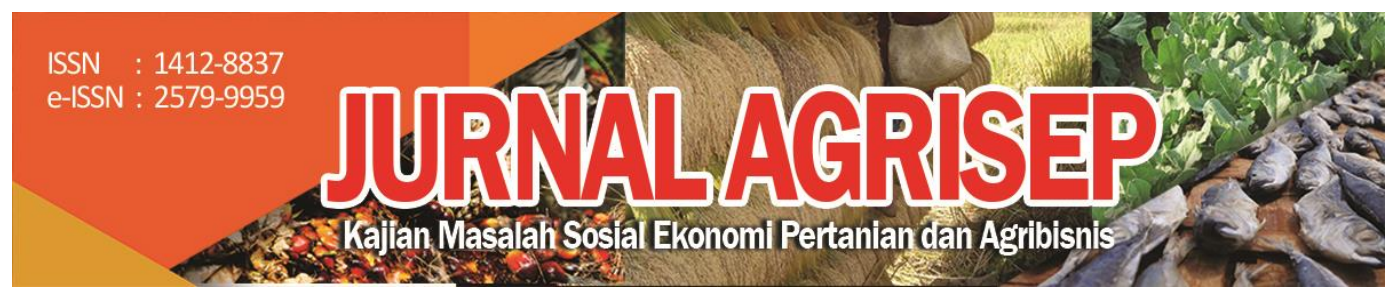

DOI: 10.31186/jagrisep.18.2.403-411

\title{
RISIKO PRODUKSI DAN EFISIENSI TEKNIS USAHATANI PADI PADA SAWAH TADAH HUJAN DI KABUPATEN MAROS, SULAWESI SELATAN
}

\section{Production Risk and Technical Effisiency of Rice Farming in Rainfed Rice Fields in Maros Regency, South Sulawesi}

\section{Arifin $\bowtie$; Zulkifli; Muhammad Arsyad Biba; Abdul Asis Pata; Mohammad Anwar Sadat \\ Program Studi Agribisnis, Fakultas Pertanian, Peternakan dan Kehutanan} Universitas Muslim Maros

Email: arifin.maros13@gmail.com

\begin{abstract}
The The agricultural production risk is greater than non-agriculture risk because agriculture strongly affected by nature such as weather, pest, diseases, temperature, drought, and flooding. The increasing of production through technical efficiency is important to do. The technical efficiency of rice farming can be improved the support or efforts of efficient use of inputs technological innovation. The aim of this study is to analyze the risk of rice farming production in rainfed rice fields. Production risk is analyzed by determining the coefficient of variation. Production risk can be measured by the amount of variance and deviation standard. Technical efficiency is used to analyze the level of technical efficiency. The results showed that rice production risk in rainfed lowland rice in Allepolea Village was greater than the production risk in Bontoa Village and Mattirotasi Village. While for technical efficiency in Mattirotasi Village, it's more technically efficient for rainfed lowland rice farming than in Bontoa Village and Allepolea Village, Maros Regency.
\end{abstract}

Keywords: Production Risk, Technical Efficiency, Rice Farming, Rainfed Rice Fields 


\begin{abstract}
ABSTRAK
Risiko produksi pertanian lebih besar dibandingkan risiko non pertanian, karena pertanian sangat dipengaruhi oleh alam seperti cuaca, hama penyakit, suhu, kekeringan, dan banjir. Peningkatan produktivitas melalui efisiensi teknis menjadi penting untuk dilakukan. Efisiensi teknis usahatani padi masih dapat ditingkatkan karena dukungan atau upaya efisiensi penggunaan input dan inovasi teknologi. Tujuan penelitian adalah menganalisis risiko produksi usahatani padi pada sawah tadah hujan, dan menganalisis efisiensi teknis usahatani padi pada sawah tadah hujan. Risiko produksi dianalisis dengan menentukan besarnya koefisien variasi. Risiko produksi dapat diukur dari besarnya variance dan standar deviasi. Efisiensi teknis digunakan analisis tingkat efisiensi teknis. Hasil penelitian menunjukkan bahwa risiko produksi usahatani padi pada lahan sawah tadah hujan di Kelurahan Allepolea lebih besar daripada risiko produksi di Kelurahan Bontoa dan Desa Mattirotasi Kabupaten Maros. Sedangkan untuk efisiensi teknis maka di Desa Mattirotasi lebih efisien secara teknis usahatani padi pada sawah tadah hujan dibanding dengan Kelurahan Bontoa dan Kelurahan Allepolea Kabupaten Maros.
\end{abstract}

Kata kunci: Risiko Produksi, Efisien Teknis, Usahatani Padi, Sawah Tadah Hujan

\title{
PENDAHULUAN
}

Sawah tadah hujan berpotensi untuk digunakan sebagai areal peningkatan produksi padi. Kendala utama pada sawah tadah hujan adalah produktivitas lahan yang jauh lebih rendah dibandingkan dengan sawah irigasi, terjadinya banjir pada musim hujan dan kekeringan pada musim kemarau (Indah, 2015). Sawah tadah hujan sebagai ekosistem yang berisiko tinggi karena terancam oleh kekeringan, kebanjiran atau kegaraman. Antisipasi risiko tersebut diupayakan melalui pemuliaan tanaman dan teknik budidaya serta pengelolaan hara tanaman padi (Arifin, 2015). Pola tanam yang dilakukan petani untuk menyiasati hal tersebut adalah dengan menanam pada akhir musim hujan. Pola tanam tersebut menyebabkan budidaya padi hanya dapat dilakukan satu kali dalam satu tahun, hal ini menyebabkan produktivitas lahan menjadi rendah. Faktor pembatas produksi lainnya adalah kesuburan tanah yang rendah, tingginya serangan hama dan kerapatan gulma (Primilestari dan Edi, 2015).

Petani dalam menjalankan usahanya dipengaruhi oleh faktor-faktor yang dapat dikontrol (internal) maupun faktor-faktor di luar kontrol (eksternal), menyebabkan petani dihadapkan pada risiko atau ketidakpastian usaha (Prihtanti, 2014; Kohansal dan Aliabadi, 2014). Semua komoditi pertanian terutama yang diusahakan oleh petani, persoalan pokoknya adalah masalah produksi (Soltesz at el. 2013). Masalah produksi terkait dengan sifat usahatani yang selalu tergantung pada alam didukung faktor risiko (Sriyadi, 2010). Risiko produksi yang paling banyak menimbulkan kerugian bagi petani adalah adanya serangan hama dan penyakit yang tidak dapat diprediksi sebelumnya. 
Dalam berbagai kegiatan usaha di bidang pertanian sering terjadi situasi ekstrim yaitu kejadian yang mengandung risiko (risk events) dan kejadian yang tidak pasti (uncertainty events). Risiko produksi pertanian lebih besar dibandingkan risiko non pertanian, karena pertanian sangat dipengaruhi oleh alam seperti cuaca, hama penyakit, suhu, kekeringan, dan banjir (Zakirin dkk, 2013; Asogwa et al. 2014; Laanemets et al. 2011; Spicka et al. 2009; Bokusheva dan Hockmann, 2006). Risiko usahatani padi yang utama antara lain frekuensi banjir, kekeringan dan serangan hama penyakit yang saat ini menjadi masalah yang semakin kompleks dalam situasi perubahan iklim yang sulit diprediksi (Suharyanto dkk, 2015; Sulewski dan Gajewska, 2014; Chavas dan Shi, 2015).

Meningkatkan produksi petani sebagai pengelola usahatani harus memahami dan mampu mengaplikasikan faktor-faktor produksinya dengan baik, bila tidak maka peningkatan produksi tidak akan tercapai. Oleh karena itu, pengalokasian penggunaan faktor-faktor produksi yang efisien dan efektif, serta mampu beradaptasi dengan perubahan iklim sangat menentukan tercapainya efisiensi usahatani (Murniati dkk, 2014; Prihtanti, 2015).

Peningkatan produktivitas melalui efisiensi teknis menjadi penting untuk dilakukan. Efisiensi teknis usahatani padi masih dapat ditingkatkan karena dukungan atau upaya efisiensi penggunaan input dan inovasi teknologi (Suharyanto dkk, 2013; Muslim, 2008). Pencapaian efisiensi selain dipengaruhi oleh jumlah dan jenis faktor produksi serta manajemen, juga dipengaruhi oleh faktor lingkungan dimana usahatani dikembangkan (Lamusa, 2009). Tujuan penelitian ini adalah menganalisis risiko produksi dan efisiensi teknis usahatani padi pada sawah tadah hujan.

\section{METODE PENELITIAN}

Penelitian ini dilakukan di Kabupaten Maros di tiga kecamatan yaitu Kecamatan Lau (Kelurahan Allepolea), Bontoa (Kelurahan Bontoa), dan Maros Baru (Desa Mattirotasi). Kabupaten Maros dipilih sebagai lokasi penelitian, dengan pertimbangan bahwa merupakan salah satu daerah yang mempunyai sawah tadah hujan yang luas di Sulawesi Selatan. Data yang dikumpulkan dalam penelitian ini meliputi data primer dan data sekunder. Untuk mengumpulkan data digunakan tiga macam teknik, yaitu observasi, pencatatan dan wawancara.

Populasi dalam penelitian adalah petani yang melakukan usahatani padi pada lahan sawah tadah hujan di lokasi penelitian. Jumlah sampel petani yang dijadikan responden adalah diambil 100 orang. Untuk mendapatkan jumlah sampel tersebut dengan menggunakan metode simple random sampling.

Risiko produksi dianalisis dengan menentukan besarnya koefisien variasi. Risiko produksi dapat diukur dari besarnya variance dan standar deviasi. Koefisien variasi secara matematis dapat dituliskan sebagai berikut : 


$$
K V=\frac{\sigma}{\bar{X}}
$$

dimana KV adalah koefisien variasi produksi; $\sigma$ adalah standar deviasi produksi (varian); $\bar{X}$ adalah rata-rata produksi; dan $\mathrm{n}$ adalah jumlah sampel

Untuk efisiensi teknis digunakan analisis sebagai berikut.

$$
T E R=\frac{Y_{i}}{\bar{Y}}
$$

dimana TER adalah tingkat efisiensi teknis; $\bar{Y}$ adalah produksi potensial; dan Yi adalah produksi aktual

\section{HASIL DAN PEMBAHASAN}

\section{Risiko Produksi Usahatani Padi pada Sawah Tadah Hujan}

Risiko produksi usahatani padi sawah tadah hujan dari tiga kecamatan dan desa di Kabupaten Maros, dapat diketahui perbedaannya dengan menggunakan analisis uji beda varian (F-test) dan koefisien variasi. Hasil analisis risiko produksi tersebut dapat di lihat pada Tabel 1.

Tabel 1. Nilai F dan Koefisien Variasi Produksi Usahatani Padi Sawah Tadah Hujan di Tiga Kecamatan Kabupaten Maros

\begin{tabular}{lrc}
\hline \multicolumn{1}{c}{ Uraian } & \multicolumn{1}{c}{ Varian } & Koefisien Variasi \\
\hline Kecamatan Lau (Kelurahan Allepolea) & $903.352,889$ & 0,575 \\
Kecamatan Bontoa (Kelurahan Bontoa) & $1.810 .900,000$ & 0,429 \\
Kecamatan Maros Baru (Desa Mattirotasi) & $1.141 .626,206$ & 0,370 \\
\hline
\end{tabular}

Uji Beda Variance :

$\begin{array}{lr}\text { F hitung (Allepolea dengan Bontoa) } & 3,058^{* *} \\ \mathrm{~F}_{\text {tabel }}(\alpha=5 \%) & (1,913) \\ \mathrm{F}_{\text {hitung }} \text { (Allepolea dengan Mattirotasi) } & 0,245 \text { ts } \\ \mathrm{F}_{\text {tabel }}(\alpha=5 \%) & (1,913) \\ \text { F }_{\text {hitung }} \text { (Bontoa dengan Mattirotasi) } & 1,549 * * \\ \mathrm{~F}_{\text {tabel }}(\alpha=5 \%) & (1,913)\end{array}$

Uji Beda Koefisien Variasi :

$\begin{array}{llc}\chi^{2} \text { hitung (Allepolea dengan Bontoa) } & - & 5,090 \text { ** } \\ \chi^{2} \text { tabel }(\alpha=5 \%) & - & (1,682) \\ \chi^{2} \text { hitung (Allepolea dengan Mattirotasi) } & - & 4,6599^{* *} \\ \chi^{2} \text { tabel }(\alpha=5 \%) & - & (1,671) \\ \chi^{2} \text { hitung }(\text { Bontoa dengan Mattirotasi) } & - & 0,827 \text { ts } \\ \chi^{2} \text { tabel }(\alpha=5 \%) & - & (1,682)\end{array}$

Keterangan: ${ }^{* *}=$ signifikan pada $\alpha: 5 \%$; ts $=$ tidak siginfikan 
Hasil analisis uji beda varian yang ditunjukkan pada Tabel 1, nilai Fhitung dan Ftabel memiliki perbedaan yang berpengaruh nyata pada petani di Kelurahan Allepolea dengan Kelurahan Bontoa, demikian juga terjadi pada petani di Kelurahan Bontoa dengan Desa Mattirotasi. Hal ini dapat dijelaskan bahwa terdapat perbedaan risiko produksi antara petani di daerah tersebut. Dimana risiko produksi pada petani di Kelurahan Allepolea lebih kecil daripada petani di Kelurahan Bontoa. Demikian juga pada petani di Kelurahan Allepolea lebih kecil risiko produksinya daripada petani Desa Mattirotasi. Perbedaan risiko produksi tersebut, terkait dimana petani di Kelurahan Allepolea tidak berani mengambil risiko apabila menginginkan memperoleh hasil produksi yang semakin besar maka dihadapkan pada risiko yang juga semakin besar. Hal ini disebabkan karena kebanyakan petani di Kelurahan Allepolea adalah petani yang kurang mampu dan hanya mengandalkan tenaga kerja dalam keluarga. Keterbatasan petani tersebut berdampak pada kemampuan dalam penggunaan input produksi untuk meningkatkan hasil usahataninya. Rata-rata penggunaan input yang digunakan masih kurang dan belum memenuhi anjuran yang seharusnya. Risiko lebih banyak digunakan dalam konteks pengambilan keputusan, karena risiko sebagai peluang akan terjadinya suatu kejadian buruk akibat suatu tindakan. Makin tinggi tingkat ketidakpastian suatu kejadian, makin tinggi pula risiko yang disebabkan oleh pengambilan keputusan (Suharyanto dkk, 2015).

Sedangkan hasil analisis uji beda varian antara petani di Kelurahan Allepolea dengan Desa Mattirotasi yang ditunjukkan pada Tabel 1, dimana nilai Fhitung dan Ftabel tidak memiliki perbedaan atau tidak berpengaruh nyata. Berarti tidak ada perbedaan risiko produksi antara petani di daerah tersebut. Dimana risiko produksi pada petani di Kelurahan Allepolea sama dengan petani di Desa Mattirotasi. Hal ini disebabkan petani di Kelurahan Allepolea dan Desa Mattirotasi mempunyai kesamaan yaitu tidak berani mengambil risiko untuk membiayai usahataninya dan juga mempunyai keterbatasan modal untuk biaya usahataninya.

Untuk besarnya nilai koefisien variasi dapat diketahui bahwa petani di Kelurahan Allepolea dengan Kelurahan Bontoa dan petani di Kelurahan Allepolea dengan Desa Mattirotasi terdapat perbedaan dalam risiko produksi. Hal ini dapat dilihat Tabel 1 dari hasil analisis uji Chi Kuadrat $\left(\chi^{2}\right)$ menunjukkan nilai $\chi 2$ hitung lebih besar dari nilai $\chi 2$ tabel, berarti risiko produksi petani di Kelurahan Allepolea lebih besar daripada risiko produksi petani di Kelurahan Bontoa dan Desa Mattirotasi. Ini memberikan arti petani di Kelurahan Allepolea lebih berani mengambil risiko dalam menjalankan usahataninya dibanding dengan petani di Kelurahan Bontoa dan Desa Mattirotasi. Zakirin dkk (2013), sumber risiko di pertanian diantaranya produksi dan risiko teknis yaitu risiko produksi yang terjadi adanya hubungan teknis antara output dan tingkat penggunaan input. 
Sedangkan besarnya nilai koefisien variasi petani di Kelurahan Bontoa dengan Desa Mattirotasi tidak terdapat perbedaan dalam risiko produksi. Hal ini dapat dilihat dari hasil analisis uji Chi Kuadrat $(\chi 2)$ pada Tabel 1, menunjukkan nilai $\chi 2$ hitung lebih kecil dari nilai $\chi 2$ tabel. Berarti risiko produksi petani di Kelurahan Bontoa lebih kecil atau sama dengan risiko produksi petani di Desa Mattirotasi. Ada kesamaan antara petani di Kelurahan Bontoa dan Desa Mattirotasi menghindari risiko atau tidak berani mengambil risiko untuk menjalankan usahataninya. Keberanian petani dalam mengambil keputusan sangat dipengaruhi oleh kondisi risiko dari usahataninya. (Prihtanti, 2014), risiko usahatani lebih banyak terkonsentrasi di pihak individu petani kecil.

\section{Efisiensi Teknis Usahatani Padi pada Sawah Tadah Hujan}

Efisiensi teknis usahatani padi pada sawah tadah hujan di tiga kecamatan dan desa Kabupaten Maros, dapat diketahui perbedaan hasilnya di tiga lokasi tersebut dengan menggunakan analisis uji $\mathrm{t}$ sampel independen (independent samples $t$ test). Manihuruk dkk (2018), petani dikatakan efisien dalam menggunakan input produksi jika memiliki nilai efisiensi teknis sebesar 1 dan tidak efisien jika kurang dari 1 . Hasil analisis efisiensi teknis dapat di lihat pada Tabel 2.

Tabel 2. Hasil Analisis Efisiensi Teknis Usahatani Padi Sawah Tadah Hujan di Tiga Kecamatan Kabupaten Maros

\begin{tabular}{|c|c|c|c|}
\hline Efisiensi Teknis & $\begin{array}{c}\text { Kec. Lau } \\
\text { (Kel. Allepolea) }\end{array}$ & $\begin{array}{l}\text { Kec. Bontoa } \\
\text { (Kel. Bontoa) }\end{array}$ & $\begin{array}{r}\text { Kec. Maros Baru } \\
\text { (Desa Mattirotasi) }\end{array}$ \\
\hline $\begin{array}{l}\text { Nilai rata-rata } \\
\text { Nilai minimum } \\
\text { Nilai maksimum } \\
\text { Persentase efisien } \\
\text { Persentase tidak } \\
\text { efisian }\end{array}$ & $\begin{array}{r}0,35 \\
0,22 \\
0,59 \\
0,00 \\
100,00\end{array}$ & $\begin{array}{r}1,11 \\
0,89 \\
1,58 \\
22,50 \\
77,50\end{array}$ & $\begin{array}{r}0,99 \\
0,79 \\
1,08 \\
73,33 \\
26,67\end{array}$ \\
\hline $\begin{array}{l}\text { Uji t Efisiensi Teknis } \\
\text { thitung (Allepole } \\
t_{\text {tabel }(a=5 \%)} \\
t_{\text {hitung }} \text { (Allepole } \\
\text { Mattirotasi) } \\
t_{\text {tabel }(\alpha=5 \%)} \\
t_{\text {hitung }}(\text { Bontoa } \mathrm{c} \\
t_{\text {tabel }(a=5 \%)}\end{array}$ & $\begin{array}{l}\text { ngan Bontoa) } \\
\text { ngan } \\
\text { an Mattirotasi) }\end{array}$ & & $\begin{array}{l}24,938 \text { ** } \\
(1,682) \\
36,102 \text { ** } \\
(1,671) \\
4,054 * * \\
(1,682)\end{array}$ \\
\hline
\end{tabular}

Keterangan: ${ }^{* *}=$ signifikan pada $\alpha: 5 \%$

408 | Arifin; Zulkifli; Muhammad Arsyad Biba; Abdul Asis Pata; Mohammad... 
Hasil analisis uji t efisiensi teknis yang ditunjukkan pada Tabel 2, dimana nilai thitung dan ttabel memiliki perbedaan yang berpengaruh nyata pada petani di Kelurahan Allepolea dengan Kelurahan Bontoa, Kelurahan Allepolea dengan Desa Mattirotasi, dan juga terjadi pada petani di Kelurahan Bontoa dengan Desa Mattirotasi. Hal ini dapat dijelaskan bahwa terdapat perbedaan efisiensi teknis antara petani di daerah tersebut. Dimana petani di Kelurahan Allepolea efisiensi teknisnya lebih kecil daripada petani di Kelurahan Bontoa. Berarti petani di Kelurahan Bontoa lebih banyak efisien secara teknis dalam hal menggunakan input produksi dalam mengelola usahatani padi pada lahan sawah tadah hujan. Suharyanto dkk (2015), walaupun telah memiliki pengalaman panjang dalam berusahatani untuk komoditas pertanian, namun petani tidak selalu dapat mencapai tingkat efisiensi dan produktivitas seperti yang diharapkan. Hal ini disebabkan salah satu faktor yang mempengaruhi adalah intensitas penggunaan input.

Untuk petani di Kelurahan Allepolea lebih kecil efisiensi teknisinya daripada petani di Desa Mattirotasi. Demikian juga petani di Kelurahan Bontoa lebih kecil efisiensi teknisnya daripada petani di Desa Mattirotasi. Berarti petani di Desa Mattirotasi lebih banyak efisien secara teknis dalam hal menggunakan input produksi dalam mengelola usahatani padi di lahan sawah tadah hujan dibandingkan dengan petani di Kelurahan Allepolea dan Kelurahan Bontoa.

Apabila diurutkan banyaknya petani yang efisien secara teknis penggunaan input produksi dalam mengelola usahatani padi di sawah tadah hujan berdasarkan lokasi, maka Desa Mattirotasi yang paling banyak petaninya efisien secara teknis dan kemudian Kelurahan Bontoa. Sedangkan petani di Kelurahan Allepolea tidak ada efisien secara teknis penggunaan input produksi. Perbedaan efisiensi teknis tersebut, terkait dengan kemampuan petani untuk mengalokasikan input produksi yang digunakan. Hal ini disebabkan karena antara petani satu dengan petani yang lain, berbeda kemampuan untuk memenuhi kebutuhan input produksi yang digunakan dalam mengelola usahataninya. Murniati dkk (2014), perbedaan tingkat efisiensi teknis yang dicapai petani mengindikasikan bahwa tingkat penguasaan dan penerapan teknologi yang berbeda-beda. Tingkat penguasaan teknologi yang berbeda-beda dari petani disebabkan oleh faktor intern dalam diri petani seperti pendidikan, umur, pengalaman berusahatani, frekuensi mengikuti penyuluhan dan faktor ektern seperti kondisi lahan.

\section{SIMPULAN DAN SARAN}

Berdasarkan hasil penelitian disimpulkan bahwa risiko produksi usahatani padi pada lahan sawah tadah hujan di Kelurahan Allepolea lebih besar daripada risiko produksi di Kelurahan Bontoa dan Desa Mattirotasi Kabupaten Maros. Sedangkan untuk efisiensi teknis maka di Desa Mattirotasi lebih efisien 
secara teknis usahatani padi pada sawah tadah hujan dibanding dengan Kelurahan Bontoa dan Kelurahan Allepolea Kabupaten Maros.

Petani perlu menambah penggunaan input produksi untuk meningkatkan produksi dan menurunkan risiko produksi serta tercapai penggunaan input yang efisien. Oleh karena itu, pihak terkait dalam hal ini pemerintah perlu memberikan dukungan kebijakan insentif baik dari sisi input maupun output sehingga usahatani padi memberikan keuntungan bagi petani.

\section{DAFTAR PUSTAKA}

Arifin, 2015. Ketahanan Pangan dan Kontribusi Usahatani Padi pada Sawah Tadah Hujan (Studi Kasus di Desa Allepolea Kecamatan Lau Kabupaten Maros). Jurnal Caliptra 14 (02) : 40 - 46.

Asogwa, BC., Abu, O., dan Ogene, A., 2014. Agricultural Risk Management and Production Efficiency among Peasant Farmers in Benue State, Nigeria. Asian Journal of Agricultural Extension, Economics \& Sociology 3 (5) : 373 391.

Bokusheva, R., dan Hockmann, H., 2006. Production risk and technical inefficiency in Russian agriculture. European Review of Agricultural Economics 33 (1) : 93 - 118.

Chavas, JP., dan Shi, G., 2015. An Economic Analysis of Risk, Management, and Agricultural Technology. Journal of Agricultural and Resource Economics $40(1): 63-79$

Indah, LSM., 2015. Analisis Efisiensi Produksi dan Risiko Usahatani Padi Sawah pada Lahan Irigasi Teknis dan Lahan Tadah Hujan di Kabupaten Lampung Selatan. Tesis. Program Pascasarjana Magister Agribisnis. Universitas Lampung. Bandar Lampung.

Kohansal, MR., dan Aliabadi, MMF., 2014. Impact of Technological Change on Wheat Production Risk in Northwest of Iran. International Journal of Agricultural Science and Technology 2 (1) : 17 - 21.

Laanemets, O,. Viira, AH., dan Nurmet, M., 2011. Price, Yield, and Revenue Risk in Wheat Production in Estonia. Agronomy Research 9 (II) : 421 - 426.

Lamusa, A., 2009. Analisis Efisiensi Teknis Alokasi Input Usahatani Padi Sawah di Daerah Impenso Wilayah Taman Nasional Lore Lindu (TNLL) Provinsi Sulawesi Tengah. Jurnal Agroland 16 (3) : 251 - 257.

Manihuruk, E., Harianto, dan Kusnadi, N., 2018. Analisis Faktor yang Memengaruhi Petani Memilih Pola Tanam Ubi Kayu serta Efisiensi Teknis di Kabupaten Lampung Tengah. AGRISEP 17 (2) : 139 - 150.

Murniati, K., Mulyo, JH., Irham, dan Hartono, S., 2014. Efisiensi Teknis Usahatani Padi Organik Sawah Tadah Hujan di Kabupaten Tanggamus Provinsi Lampung. Jurnal Penelitian Pertanian Terapan 14 (1) : 31 - 38. 
Muslim, A., 2008. Analisis Tingkat Efisiensi Teknis dalam Usahatani Padi dengan Fungsi Produksi Frontir Stokastik. Jurnal Ekonomi Pembangunan $13(3): 191$ - 206.

Prihtanti, TM., 2015. Analisis Efisiensi Usahatani Padi Organik dan Konvensional : Sebuah Tinjauan Singkat. Prosiding Konser Karya Ilmiah 1: $34-41$.

Prihtanti, TM., 2014. Analisis Risiko Berbagai Luas Penguasaan Lahan pada Usahatani Padi Organik dan Konvensional. AGRIC 26 (1 \& 2) : 29 - 36.

Primilestari, S., dan Edi, S., 2015. Penerapan Teknologi untuk Meningkatkan Produksi Padi Sawah pada Lahan Tadah Hujan Kota Jambi. Prosiding. Seminar Nasional Lahan Suboptimal. Palembang.

Soltesz, A., Szoke, S., dan Balogh, P., 2013. Analysis of Economic Risks in Sow Production. Journal of Agricultural Informatics 4 (2) : 10 - 21.

Spicka, J., Boudny, J., dan Janotova, B., 2009. The Role of Subsidies in Managing the Operating Risk. AGRIC. ECON 55 (4) : 169 - 179.

Sriyadi, 2010. Risiko Produksi dan Keefisienan Relatif Usahatani Bawang Putih di Kabupaten Karanganyar. Jurnal Pembangunan Pedesaan 10 (2) : 69 - 76.

Suharyanto, Rinaldy, M., dan Ngurah Arya, N., 2015. Analisis Risiko Produksi Usahatani Padi Sawah di Propinsi Bali. Jurnal Agraris. 1 (2) : 70 - 77.

Suharyanto, Mulyo, JH., Darwanto, DH., dan Widodo, S., 2013. Analisis Efisiensi Teknis Pengelolaan Tanaman Terpadu (PTT) Padi Sawah di Provinsi Bali. Jurnal SEPA 9 (2) : 219 - 230.

Sulewski, P., and Gajewska, AK., 2014. Farmers Risk Perception, Risk Aversion and Strategies to Cope with Production Risk: an Empirical Study from Poland. Studies in Agricultural Economics $116: 140$ - 147

Zakirin, M., Yurisinthae, E., dan Kusrini, N., 2013. Analisis Risiko Usahatani Padi pada Lahan Pasang Surut di Kabupaten Pontianak. Jurnal Social Economic of Agriculture 2 (1) : 75 - 84. 